triggering data gathering, including wiretaps, and does not clearly specify that judicial oversight must occur prior to data collection. ${ }^{21}$

Overall, the CLOUD Act set the stage for a shift away from the traditional MLATs, and the U.S.-UK Data Access Agreement begins the implementation of this shift. As the first bilateral CLOUD Act agreement, it may serve as a model for future such agreements. The U.S. attorney general and Australian minister for home affairs announced on October 7, 2019, that the two nations are formally negotiating an agreement under the CLOUD Act. ${ }^{22}$ Additionally, in June of 2019, the Council of the European Union formally authorized the European Commission to "open negotiations for an agreement between the Union and the United States of America on cross-border access by judicial authorities in criminal proceedings to electronic evidence held by a service provider." 23

\title{
United States Remains in the Universal Postal Union, Rescinding Its Notice of Withdrawal
} doi:10.1017/ajil.2019.84

On September 25, 2019, the Third Extraordinary Congress of the Universal Postal Union (UPU) adopted a proposal on terminal dues rates - a decision that led the United States to remain a member state. The United States had given its one-year notice of withdrawal from the UPU eleven months earlier, citing concerns that the existing system unfairly advantaged

${ }^{21}$ Coalition letter from EPIC et. al. to U.S. Members of Congress (Oct. 29, 2019), available at https://www. whistleblower.org/sign-on-letter/sign-on-coalition-statement-re-u-s-u-k-cloud-act-executive-agreement [https:// perma.cc/9Y67-P3XT] (observing that "the text of the U.S.-U.K. Agreement requires that orders for content, widely considered the most sensitive electronic data, only meet the standard of 'reasonable justification based on articulable and credible facts, particularly, legality, and severity" and stating that this "standard is vague ... and likely is weaker than probable cause in various contexts"). By contrast, Jennifer Daskal and Peter Swire describe the U.S.-UK Data Access Agreement and the underlying CLOUD Act as "positive developments that protect privacy and civil liberties, accommodate divergent norms across borders, and respond to the reality that digital evidence critical even to wholly local crimes is often located across international borders." Jennifer Daskal \& Peter Swire, The UK-US CLOUD Act Agreement Is Finally Here, Containing New Safeguards, Just SeCurITY (Oct. 8, 2019), at https://www.justsecurity.org/66507/the-uk-us-cloud-act-agreement-is-finally-here-containing-newsafeguards.

${ }^{22}$ U.S. Dep't of Justice Press Release, Joint Statement Announcing United States and Australian Negotiation of a CLOUD Act Agreement by U.S. Attorney General William Barr and Minister for Home Affairs Peter Dutton (Oct. 7, 2019), at https://www.justice.gov/opa/pr/joint-statement-announcing-united-states-and-australiannegotiation-cloud-act-agreement-us [https://perma.cc/MH2H-ZVEX].

${ }^{23}$ Council of the European Union, Council Decision Authorising the Opening of Negotiations with a View to Concluding an Agreement Between the European Union and the United States of America on Cross-Border Access to Electronic Evidence for Judicial Cooperation in Criminal Matters, COPEN 268 USA 45, 10128/19 (June 12, 2019), available at https://data.consilium.europa.eu/doc/document/ST-10128-2019-INIT/en/pdf [https://perma.cc/2XJF-KUZC]; $c f$. European Data Protection Supervisor, Initial Legal Assessment of the Impact of the US CLOUD Act on the EU Legal Framework for the Protection of Personal Data and the Negotiations of an EU-US Agreement on Cross-Border Access to Electronic Evidence (July 10, 2019), available at https://edpb.europa.eu/sites/edpb/files/files/file2/edpb_edps_joint_response_us_cloudact_annex.pdf [https:// perma.cc/2FY7-YWYB] (assessing some legal issues related to the CLOUD Act and its interaction with the EU's General Data Protection Regulation). 
certain developing nations, including China. Following the UPU's decision, the United States rescinded its notice of withdrawal. Under the new system, the United States can begin self-posting terminal dues rates in July 2020.

On August 23, 2018, President Trump issued a memorandum laying out the priorities of the administration in its negotiations at the UPU. ${ }^{1}$ This memorandum focused on the rates that post offices in different countries charge each other for the delivery of international mail. Under the existing UPU framework, which stemmed back to 1969, terminal due rates were based on a country classification system whereby developed nations such as the United States paid more than developing nations. ${ }^{2}$ In the memorandum, Trump expressed concern about this system and stated:

(A) the United States, along with other member countries of the UPU, is in many cases not fully reimbursed by the foreign postal operator for the cost of delivering foreignorigin letter post items, which can result in substantial preferences for foreign mailers relative to domestic mailers;

(B) the current terminal dues rates undermine the goal of unrestricted and undistorted competition in cross-border delivery services because they disadvantage non-postal operators seeking to offer competing collection and outward transportation services for goods covered by terminal dues in foreign markets; and

(C) the current system of terminal dues distorts the flow of small packages around the world by incentivizing the shipping of goods from foreign countries that benefit from artificially low reimbursement rates. ${ }^{3}$

The memorandum also observed that if U.S. concerns were not promptly addressed by the UPU, the United States would "consider taking any appropriate actions" to ensure its criteria were met. ${ }^{4}$

While Trump's memorandum did not discuss China by name, his concerns had particular resonance with respect to that country. Peter Navarro, the White House director of trade and manufacturing policy, later wrote in an opinion piece:

$[U]$ nder the [UPU]'s antiquated "terminal dues" system, the United States Postal Service was being forced to subsidize a flood of small packages, primarily from China, at an annual cost in the neighborhood of $\$ 500$ million.

\footnotetext{
${ }^{1}$ Modernizing the Monetary Reimbursement Model for the Delivery of Goods Through the International Postal System and Enhancing the Security and Safety of International Mail, 83 Fed. Reg. 183 (Aug. 23, 2018) [hereinafter Presidential Memorandum].

${ }^{2}$ See id.; Universal Postal Union, About Terminal Dues and Transit Charges, at http://www.upu.int/en/activities/terminal-dues-and-transit-charges/about-terminal-dues-and-transit-charges.html [https:/perma.cc/5ZUZQPZT].

${ }^{3}$ Presidential Memorandum, supra note 1.

${ }^{4}$ Id. For more information, see Eliot Kim, Withdrawal from the Universal Postal Union: A Guide for the Perplexed, LAWFARE (Oct. 31, 2018), at https://www.lawfareblog.com/withdrawal-universal-postal-union-guideperplexed.
} 
This forced subsidy gave China an unfair advantage against American manufacturers and workers .... 5

Several months after Trump's memorandum, the UPU held its Second Extraordinary Congress. ${ }^{6}$ Following unsuccessful negotiations, on October 15, 2018, Secretary of State Mike Pompeo notified the UPU that the United States "hereby denounces the UPU Constitution and, thereby, withdraws from the Universal Postal Union. Pursuant to Article 12 of the Constitution, the withdrawal of the United States shall be effective one year after the day on which you receive this notice of denunciation." 7 The United States was a founding member of the UPU, as a signatory to the 1874 Treaty of Berne, ${ }^{8}$ and had an "unbroken record of participation" in it. . In a statement regarding the withdrawal, the Trump administration announced that "the Department of State will seek to negotiate bilateral and multilateral agreements that resolve the problems discussed in the Presidential Memorandum. If negotiations are successful, the administration is prepared to rescind the notice of withdrawal and remain in the UPU." ${ }^{10}$ Media reports characterized the exit as another move in growing trade tensions with China. ${ }^{11}$

After the United States gave its notice of withdrawal, the UPU called for a Third Extraordinary Congress, as recommended by the UPU's Council of Administration. ${ }^{12}$ The Third Extraordinary Congress convened in Geneva, Switzerland, from September 23-26, 2019. ${ }^{13}$ Leading the negotiations for the United States, Navarro offered support for two potential resolutions with respect to terminal dues rates: first for a measure where "all members of the UPU would be allowed to immediately self-declare rates;" ${ }^{14}$ or second for a

\footnotetext{
${ }^{5}$ Peter Navarro, Opinion, The Trump Guide to Diplomacy, N.Y. Times (Oct. 15, 2019), at https://www. nytimes.com/2019/10/15/opinion/trump-universal-postal-union.html.

${ }^{6}$ The UPU can call an Extraordinary Congress outside of its usual four-year sessions with the consent of twothirds of its member countries. Constitution of the Universal Postal Union, Art. 15, July 10, 1964, 16 UST 1291, 611 UNTS 7. The First Extraordinary Congress was held in 1900 and, in 2016, the UPU decided to hold a Second Extraordinary Congress in 2018. Universal Postal Union, 2018 Extraordinary Congress, at http://www.upu.int/en/ the-upu/congress/past-congresses/2018-extraordinary-congress.html [https://perma.cc/73JJ-BSY2].

7 U.S. State Dep't, Digest of United States Practice in International Law 113-14 (2018), available at https://www.state.gov/wp-content/uploads/2019/10/2018-Digest-Chapter-4.pdf [https://perma.cc/VG5DPS56]; see also Jean Galbraith, Contemporary Practice of the United States, 113 AJIL, 136-37 (2019) (providing more detail).

${ }^{8}$ See Galbraith, supra note 7, at 138 (also noting that the United States joined the Treaty of Berne "not via the advice and consent of the Senate, but rather as an ex ante congressional-executive agreement that relied on preexisting authority delegated by Congress to the president and the post-master general").

${ }^{9}$ Presidential Memorandum, supra note 1.

${ }^{10}$ White House Press Release, Statement from the Press Secretary (Oct. 17, 2018), at https://www.whitehouse. gov/briefings-statements/statement-press-secretary-38 [https://perma.cc/LQ8V-BAHR].

${ }^{11}$ See, e.g., Glenn Thrush, Trump Opens New Front in His Battle With China: International Shipping, N.Y. Times (Oct. 17, 2018), at https://www.nytimes.com/2018/10/17/us/politics/trump-china-shipping.html; Danielle Paquette, Trump Ditches 144-Year-Old Postal Pact that Boosts Chinese Retailers, Wash. Post (Oct. 17, 2018), at https://www.washingtonpost.com/business/economy/trump-ditches-144-year-old-postal-pact-thatboosts-chinese-retailers/2018/10/17/88aefea6-d234-11e8-8c22-fa2ef74bd6d6_story.html; see also Galbraith, supra note 7 , at 132 .

${ }^{12}$ Universal Postal Union, About Congress, at http://www.upu.int/en/the-upu/congress/about-congress.html [https://perma.cc/8D65-BQ95].

${ }^{13} I d$.

${ }^{14}$ U.S. Mission to Int'l Orgs. in Geneva Press Release, Peter Navarro, Assistant to the President \& Dir. of the Office of Trade and Mfg. Policy, Remarks Before the Universal Postal Union Third Extraordinary Congress (Sept.
} 
"multispeed option," which "would allow the United States to immediately self-declare rates while other countries would achieve that goal over a five-year period." 15 The option preferred by the United States, to immediately move for self-declared rates, was rejected by the UPU Congress on the first day of the session by a vote of 78-57. ${ }^{16}$ China was amongst those countries opposing this option. ${ }^{17}$

The next day, on September 25, the UPU membership unanimously adopted a proposal along the lines of the other option proposed by Navarro. ${ }^{18}$ The UPU press release announcing the adoption of this proposal stated:

The agreement approved by acclamation by member countries on 25 September sees the UPU accelerate rate increases to the system for remunerating the delivery of inbound international bulky letters and small packets. Self-declared rates are to be phased in starting as soon as 2020 .

Under the agreed solution, member countries that meet certain requirements - including inbound letter-post volumes in excess of 75,000 metric tonnes-would be able to opt-in to self-declare their rates starting 1 July 2020. Thresholds are included to protect lowvolume, developing countries from the impact of the swift reform. ${ }^{19}$

Media reports indicate that the United States, which has above 75,000 tons of mail imports, can start setting its rates on July 1, 2020, and other high-volume importers can start implementing their own rates in 2021 with a five-year phase-in period. ${ }^{20}$ Following the proposal's adoption, the United States gave formal notice that it would remain in the UPU. ${ }^{21}$

China expressed support for "'a positive solution and compromise in the spirit of UPU."'22 The Chinese Postal Bureau Deputy Director Gao Hongtao stated that China expected to pay almost triple for terminal dues in the future and that this would "'push up the cost of

24, 2019), at https://geneva.usmission.gov/2019/09/24/remarks-of-peter-navarro-before-the-universal-postalunion-third-extraordinary-congress [https://perma.cc/S76M-X4ML].

${ }^{15} \mathrm{Id}$.

${ }^{16}$ Jamey Keaten, World Postal Union Rejects Trump's Favored Reform Platform, Assoc. Press (Sept. 24, 2019), at https://apnews.com/30d73d7eb31241709ea3aee64afb23bb.

17 Id.

${ }^{18}$ See Universal Postal Union Press Release, UPU Third Extraordinary Congress Wraps with Strong Solidarity Message (Sept. 26, 2019), at http://news.upu.int/no_cache/nd/upu-third-extraordinary-congress-wraps-withstrong-solidarity-message [https://perma.cc/B9S5-HWKW] [hereinafter UPU Press Release]; U.S. Mission to Int'l Orgs. in Geneva Press Release, Peter Navarro, Assistant to the President \& Dir. of the Office of Trade and Mfg. Policy, Press Statement (Sept. 25, 2019), at https://geneva.usmission.gov/2019/09/25/58203 [https://perma.cc/Q3P9-AYT2].

${ }^{19}$ UPU Press Release, supra note 18.

${ }^{20}$ Stephanie Nebehay, U.N. Postal Union Clinches Deal to Keep U.S. in Club, Reuters (Sept. 25, 2019), at https:// www.reuters.com/article/us-un-postal/un-postal-union-clinches-deal-to-keep-us-in-club-idUSKBN1WA247. For more details on the specifics, see Universal Postal Union, Option V-Moving Towards Self-Declared Rates, YouTube (Oct. 16, 2019), available at https://www.youtube.com/watch?v=WOZJV6HunYQ.

${ }^{21}$ Universal Postal Union Press Release, UPU Head Meets with US President Following Geneva Agreement on Remuneration Rates (Oct.16, 2019), at http://news.upu.int/no_cache/nd/upu-head-meets-with-us-presidentfollowing-geneva-agreement-on-remuneration-rates [https://perma.cc/2FLB-LZQC].

${ }^{22}$ Nebehay, supra note 20 (quoting a member of the Chinese delegation to the UPU). 
cross-border e-commerce logistics in China, bringing a certain impact," but that the impact would be small as China would also receive a greater amount in terminal dues. ${ }^{23}$

Since Trump took office, the United States has withdrawn from a number of international agreements, including the Optional Protocol to the Vienna Convention on Diplomatic Relations, the Intermediate-Range Nuclear Forces Treaty, and the United Nations Educational, Scientific and Cultural Organization. ${ }^{24}$ Unlike with the UPU, the notices of withdrawal given with respect to these agreements did not lead to renegotiation and the rescission of the withdrawals. Media reports indicate that the administration is considering withdrawing from yet another multilateral treaty, the Open Skies Treaty, which allows parties to engage in unarmed surveillance missions over each other's territories. ${ }^{25}$

International Oceans, Environment, Health, and Aviation LaW United States Gives Notice of Withdrawal from Paris Agreement on Climate Change doi:10.1017/ajil.2019.82

On November 4, 2019, the Trump administration notified the United Nations that the United States was withdrawing from the Paris Agreement, prompting expressions of regret from a number of countries. Although President Trump had announced in June 2017 that the United States intended to withdraw from the Paris Agreement, its terms had prevented the United States from giving formal notice of withdrawal until November 4, 2019. The withdrawal will take effect on November 4, 2020. Domestically, the governors of many U.S. states responded to the withdrawal by reaffirming their commitment to the goals of the Paris Agreement, consistent with recurring tensions between the Trump administration and progressive states with respect to climate. In another major manifestation of these tensions, on October 23, 2019, the United States sued California over the state's cap-and-trade agreement with Quebec, Canada, alleging that this agreement is an unconstitutional exercise of foreign affairs powers.

Opened for signature in April of 2016, the Paris Agreement seeks to maintain the global average temperature "well below $2^{\circ} \mathrm{C}$ above pre-industrial levels and pursu[e] efforts to limit the temperature increase to $1.5^{\circ} \mathrm{C}$ above pre-industrial levels." 1 Each state party is required to "prepare, communicate and maintain successive nationally

${ }^{23}$ China Says Postal Fees to Rise After US Complaint, Assoc. Press (Oct. 15, 2019), at https://apnews.com/ 1e7020752c854accb3279aaba52cfb14.

${ }^{24}$ For more details, see generally Galbraith, supra note 7; Jean Galbraith, Contemporary Practice of the United States, 112 AJIL 107 (2018).

25 David Welna, Closing the Open Skies, NPR (Nov. 3, 2019), at https://www.npr.org/2019/11/03/ 775818736/closing-the-open-skies.

${ }^{1}$ Paris Agreement, Art. 2(1)(a), opened for signature Apr. 22, 2016, TIAS No. 16-1104. 